\title{
CONTROL STRATEGY EVALUATION FOR COMBINED N AND P REMOVAL USING A BENCHMARK WASTEWATER TREATMENT PLANT
}

\author{
Krist Gernaey", Miguel Mussati", Zhiguo Yuan ${ }^{* * *}$, \\ Marinus K. Nielsen ${ }^{* * *}$ and Sten Bay Jørgensen*"
* CAPEC, Department of Chemical Engineering, Technical University of Denmark, DK- 2800 Lyngby, Denmark
** The Advanced Wastewater Management Centre, The University of Queensland, QLD 4072 Australia
*** Krüger A/S, Gladsaxevej 363, DK-2860 Søborg, Denmark

\begin{abstract}
The COST wastewater treatment plant simulation benchmark is a useful example for evaluation of control strategies aiming at improving biological nitrogen removal. In the SMAC project, the phosphorus removal process, based on the ASM2d model, was added as an extension to the existing benchmark wastewater treatment plant. This results in an example for evaluation of control strategies for combined nitrogen and phosphorus removal from wastewater, a necessity in the frame of the SMAC project. The phosphorus removal treatment plant is illustrated via a case study, where the addition of extra carbon source and metal salts for improving phosphorus removal are considered.
\end{abstract}

Keywords: Control applications, Environmental engineering, Models, Water pollution

\section{INTRODUCTION}

In recent years an Activated Sludge Model No 1 (Henze et al., 1987) based benchmark wastewater treatment plant has been developed as an example to evaluate nitrogen $(\mathrm{N})$ removal control strategies (Pons et al., 2001). A complete description of the benchmark wastewater treatment plant (WWTP) was given by Copp (2001). The COST workgroup, which developed the benchmark discusses at this moment possible extensions to the benchmark configuration with new process units. These include a buffer tank (Pons and Corriou, 2001), a primary clarifier and an anaerobic digester (Pons et al., 2001). The workgroup also considers to modify some of the benchmark constraints, to allow the implementation of innovative control strategies. New manipulated variables have been proposed, in addition to the currently used internal recycle flow rate and the air flow rate. These new manipulated variables include the sludge waste flow rate, the sludge recycle flow rate, and the flow rate of additional carbon source that is dosed to an anoxic tank to enhance denitrification. More sophisticated control strategies may require adding extra anoxic tanks to the current benchmark configuration, or distributing the influent flow along the biological reactor.

The purpose of this paper is to demonstrate the capabilities of a biological phosphorus removal plant model to evaluate control strategies. The paper first describes the model development and then illustrates the model with a case study.

\section{PROPOSED MODIFICATIONS TO THE BENCHMARK WWTP}

\subsection{Phosphorus removal}

The present benchmark WWTP has proven very useful for the evaluation of control strategies developed for $\mathrm{N}$ removal wastewater treatment plants. However, in the frame of the SMAC project (SMArt Control of wastewater systems) the current benchmark wastewater treatment plant is not sufficiently flexible. Optimisation of phosphorus (P) removal processes is one of the key issues in the SMAC project. At this moment $\mathrm{P}$ removal is not considered in the COST benchmark plant configuration possibly due to lack of general agreement on the model that should be applied to 
model biological $\mathrm{P}$ (bio-P) removal processes. Indeed, in recent years a number of models have been proposed to describe biological P (e.g. Henze et al., 1995, 1999; Barker and Dold, 1997, Brdjanovic, 1998). For the SMAC project it was decided to model the bio-P process using the ASM2d model (Henze et al., 1999). Additional to biological processes, ASM2d also describes chemical P precipitation. An ASM2d based WWTP benchmark can as such be used to evaluate whether dosage of extra carbon source to enhance biological P removal, or dosage of a metal salt to promote chemical $\mathrm{P}$ precipitation is the most economic method to improve $\mathrm{P}$ removal.

\section{$\underline{\text { Influent composition }}$}

The ASM1 model has 13 components, and these do not include suspended solids (SS). The ASM2d model consists of 19 components, including SS. A nice feature of the ASM2d model is that the mass balance for both $\mathrm{N}$ and $\mathrm{P}$ are closed, contrary to the ASM1 model. This is very helpful in evaluating steady-state simulation results.

The influent for the ASM2d benchmark WWTP was generated based on the available ASM1 influent composition (Copp, 2001). The following assumptions were made:

- The ASM1 component $\mathrm{S}_{\mathrm{S}}$ (readily biodegradable substrate) consists of $40 \% \quad \mathrm{~S}_{\mathrm{A}}$ (acetate, fermentation products) and $60 \% \mathrm{~S}_{\mathrm{F}}$ (fermentable, rapidly biodegradable substrate), based on the reference wastewater composition given by Henze et al. (1999). $\mathrm{S}_{\mathrm{A}}$ and $\mathrm{S}_{\mathrm{F}}$ are the two components used in ASM2d for soluble, readily biodegradable COD.

- The COD:N and COD:P ratios of organic compounds are as suggested in ASM2d. These ratios can be found in Henze et al. (1999)

- $\quad$ The total amount of biodegradable $\mathrm{N}$ (= organic $\mathrm{N}+$ ammonium $\mathrm{N}$ ) in the ASM2d influent was the same as in the ASM1 influent. This means that the total amount of $\mathrm{N}$ in the ASM2d model influent was actually slightly higher because in the ASM2d model the total influent $\mathrm{N}$ also includes $\mathrm{N}$ contained in the inert (= nonbiodegradable) soluble $\left(\mathrm{S}_{\mathrm{I}}\right)$ and particulate $\left(\mathrm{X}_{\mathrm{I}}\right)$ COD fractions.
- The influent orthophosphate concentration $\left(\mathrm{S}_{\mathrm{PO} 4}\right)$ was proportional to the influent ammonium $\left(\mathrm{S}_{\mathrm{NH} 4}\right)$ concentration. The ratio between both soluble components was based on the reference wastewater composition of Henze et al. (1999).

The final flow weighted average dry weather influent composition for the ASM2d model is given in Table 1 .

Table 1. Final flow weighted average dry weather influent composition for the ASM2d model benchmark wastewater treatment plant

\begin{tabular}{lcc|lcc}
\hline Comp. & Conc. & Unit & Comp. & Conc. & Unit \\
\hline $\mathrm{S}_{\mathrm{n}}$ & 0.00 & $\mathrm{mg}-\mathrm{COD} / 1$ & $\mathrm{X}_{\mathrm{I}}$ & 51.20 & $\mathrm{mg} \mathrm{COD} / 1$ \\
$\mathrm{~S}_{\mathrm{F}}$ & 41.70 & $\mathrm{mg} \mathrm{COD} / 1$ & $\mathrm{X}_{\mathrm{S}}$ & 202.32 & $\mathrm{mg} \mathrm{COD} / 1$ \\
$\mathrm{~S}_{\mathrm{A}}$ & 27.80 & $\mathrm{mg} \mathrm{COD} / 1$ & $\mathrm{X}_{\mathrm{H}}$ & 28.17 & $\mathrm{mg} \mathrm{COD} / 1$ \\
$\mathrm{~S}_{\mathrm{I}}$ & 30.00 & $\mathrm{mg} \mathrm{COD} / 1$ & $\mathrm{X}_{\mathrm{PAO}}$ & 0.00 & $\mathrm{mg} \mathrm{COD} / 1$ \\
$\mathrm{~S}_{\mathrm{NH} 4}$ & 40.04 & $\mathrm{mg} \mathrm{N} / 1$ & $\mathrm{X}_{\mathrm{PP}}$ & 0.00 & $\mathrm{mg} \mathrm{P} / 1$ \\
$\mathrm{~S}_{\mathrm{N} 2}$ & 0.00 & $\mathrm{mg} \mathrm{N} / 1$ & $\mathrm{X}_{\mathrm{PHA}}$ & 0.00 & $\mathrm{mg} \mathrm{COD} / 1$ \\
$\mathrm{~S}_{\mathrm{NOX}}$ & 0.00 & $\mathrm{mg} \mathrm{N} / 1$ & $\mathrm{X}_{\mathrm{A}}$ & 0.00 & $\mathrm{mg} \mathrm{COD} / 1$ \\
$\mathrm{~S}_{\mathrm{PO} 4}$ & 9.01 & $\mathrm{mg} \mathrm{P} / 1$ & $\mathrm{X}_{\mathrm{TSS}}$ & 215.49 & $\mathrm{mg} \mathrm{SS} / 1$ \\
$\mathrm{~S}_{\mathrm{ALK}}$ & 7.00 & $\mathrm{mmol} \mathrm{HCO} / 1$ & $\mathrm{X}_{\mathrm{MeOH}}$ & 0.00 & $\mathrm{mg} \mathrm{SS} / 1$ \\
& & & $\mathrm{X}_{\mathrm{MeP}}$ & 0.00 & $\mathrm{mg} \mathrm{SS} / 1$
\end{tabular}

\section{RESULTS AND DISCUSSION}

\subsection{Simulation environment}

Modelling and simulations were done in a MATLAB/SIMULINK environment (Mathworks, Inc). The layout and the dimensions of the COST benchmark wastewater treatment plant (Copp, 2001) were chosen as a case study to illustrate possible wastewater treatment plant control applications of the ASM2d model. The plant layout is given in Figure I. The plant consists of 2 anoxic tanks of $1000 \mathrm{~m}^{3}$ each, and 3 aerated tanks of $1333 \mathrm{~m}^{3}$ each. The settler has a volume of $6000 \mathrm{~m}^{3}$ and is modelled with a 10-layer settler model (Takacs et al., 1991). There are two measurements available: nitrate $\mathrm{N}$ in the second anoxic tank, and dissolved oxygen $\left(\mathrm{S}_{\mathrm{O} 2}\right)$ in the last aerobic tank. The internal recycle returns nitrate rich mixed liquor to the anoxic reactors, where it can be denitrified using influent COD as an electron donor. There are two manipulated variables: the internal recycle flow rate and the oxygen transfer coefficient $\left(\mathrm{K}_{\mathrm{L}} \mathrm{a}\right)$ to the last aerobic reactor. A PI algorithm was

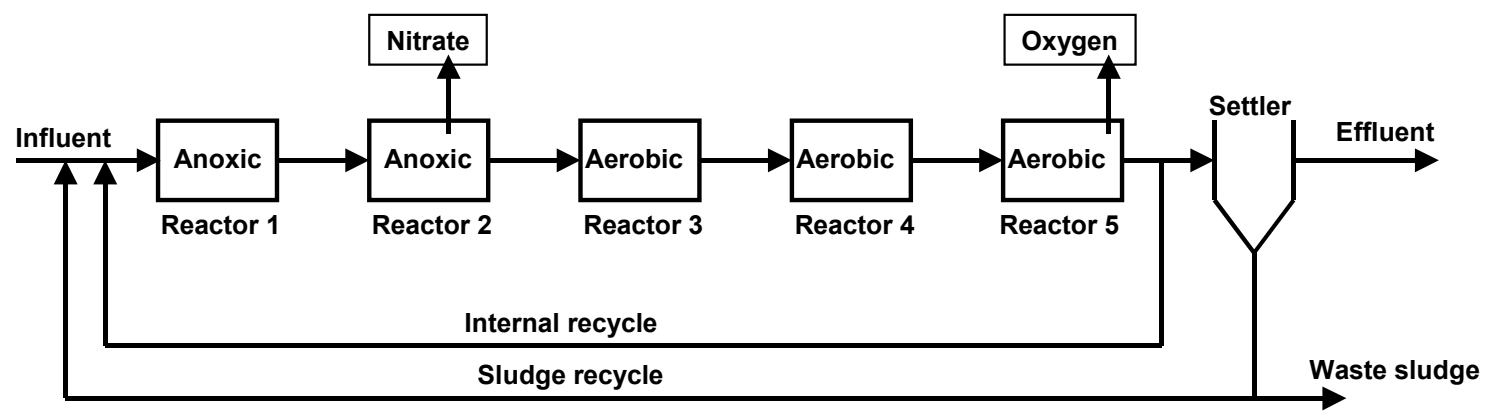

Figure I. Lay-out of the COST benchmark wastewater treatment plant (Copp, 2001) 
used for both controllers, and they were implemented according to the description given by Copp (2001). The internal recycle flow rate is controlled based on the nitrate measurement. The $\mathrm{K}_{\mathrm{L}} \mathrm{a}$ to the last aerobic reactor is controlled based on the dissolved oxygen measurement. A detailed description of the controllers is given in Copp (2001). The analysis will focus on improving the $\mathrm{P}$ removal capacity of the plant, without changing the plant layout. In the analysis, it is assumed that an $\mathrm{S}_{\mathrm{PO} 4}$ measurement, one dosage pump and an extra control loop are available to extend the plant.

\subsection{Evaluation of the ASM2d model in the COST benchmark configuration}

The treatment plant layout shown in Figure I was first simulated using the ASM2d model and the influent composition given in Table 1 . The reference ASM2d kinetic parameters for $15 \mathrm{deg} \mathrm{C}$ were used (Henze et al., 1999). All simulation runs defined in the ASM1 COST benchmark (Copp, 2001) were done (150 days open loop with constant influent; open loop $2 * 14$ days with variable dry weather influent; closed loop 150 days with no noise on measurements and constant influent; closed loop 2 * 14 days with noise on measurements and variable dry weather influent). Only the two standard controllers defined in the COST benchmark (internal recycle flow rate and $\mathrm{K}_{\mathrm{L}} \mathrm{a}$ in reactor 5 ) were active during the closed loop simulations.

The last 7 days of simulation results of the last closed loop simulation with variable dry weather influent will be discussed further. This last simulation, similar to the previous ones with constant influent composition, showed that $\mathrm{P}$ removal was not possible when using the current treatment plant layout. This can clearly be concluded from the influent and effluent $\mathrm{S}_{\mathrm{PO} 4}$ concentrations shown in Figure II.

Several reasons can be found to explain the poor Premoval performance. First of all, the influent to the treatment plant does not contain sufficient acetate $\left(\mathrm{S}_{\mathrm{A}}\right)$. As a consequence, there is insufficient removal of nitrate $\left(\mathrm{S}_{\mathrm{NOX}}\right)$ via denitrification in the first anoxic tank, and anaerobic conditions (= absence of $\mathrm{S}_{\mathrm{NOX}}$ and $\mathrm{S}_{\mathrm{O} 2}$ ) could not be established in the anoxic tank, as is illustrated in Figure III. A reactor with anaerobic condition is a necessity for the development of stable biological $\mathrm{P}$ removal in an activated sludge plant. During the anaerobic phase, the biological $\mathrm{P}$ removal bacteria take up $\mathrm{S}_{\mathrm{A}}$ and release $\mathrm{S}_{\mathrm{PO} 4} \cdot \mathrm{S}_{\mathrm{A}}$ is stored internally as storage polymers $\left(\mathrm{X}_{\mathrm{PHA}}\right.$ in the ASM2d model). In a subsequent anoxic and/or aerobic phase $\mathrm{X}_{\mathrm{PHA}}$ is consumed as energy source while the biological $\mathrm{P}$ removal bacteria take up $\mathrm{S}_{\mathrm{PO} 4}$, and store it internally as polyphosphate $\left(\mathrm{X}_{\mathrm{PP}}\right.$ in ASM2d). Normally the $\mathrm{S}_{\mathrm{PO} 4}$ uptake during the anoxic/aerobic phase is higher than the amount of $\mathrm{S}_{\mathrm{PO} 4}$ that was previously released during the anaerobic phase, resulting in a net $\mathrm{P}$ removal. $\mathrm{P}$ is removed from the system via the waste activated sludge.

A second reason for the poor P-removal efficiency is the high influent ammonium $\left(\mathrm{S}_{\mathrm{NH} 4}\right)$ concentration. $\mathrm{S}_{\mathrm{NH} 4}$ oxidation produced considerable amounts of $\mathrm{S}_{\mathrm{NOX}}$ in the aerobic reactors, and $\mathrm{S}_{\mathrm{NOX}}$ is subsequently pumped to the anoxic tanks using the internal recycle (see Figure I). Finally, the plant layout is not really suited to induce biological $\mathrm{P}$ removal. Indeed, it would probably be easier to induce biological $P$ removal in this plant if the $S_{\text {NOX }}$ rich mixed liquor was introduced to the second anoxic tank instead of to the first one (see Figure I), such that the influent COD could be more efficiently used for $\mathrm{S}_{\mathrm{PO} 4}$ release in the first tank, which would presumably be anaerobic. However, even in that case considerable amount of $\mathrm{S}_{\mathrm{NOX}}$ would be introduced in the first reactor via the recycle sludge.
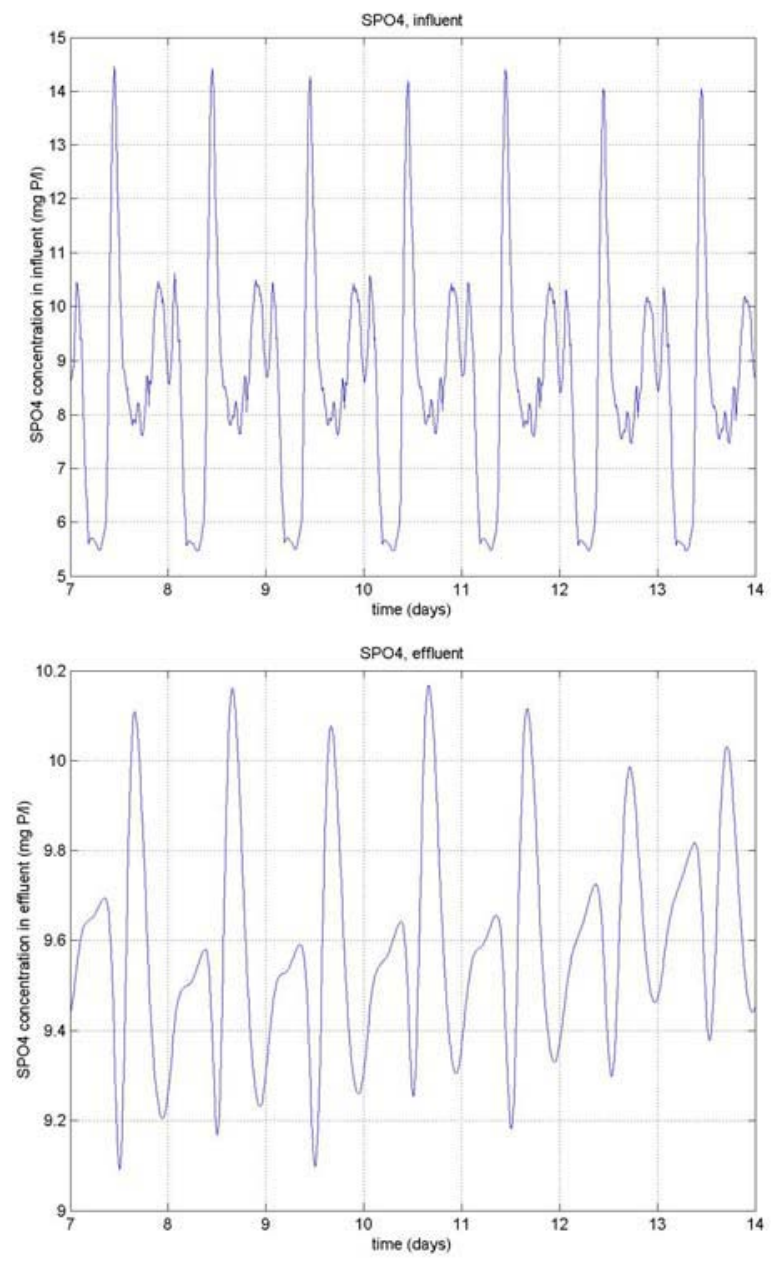

Figure II. Influent (top) and effluent $\mathrm{S}_{\mathrm{PO} 4}$ (bottom) resulting from the ASM2d based simulation of the WWTP in Figure I (variable influent composition, closed loop) 


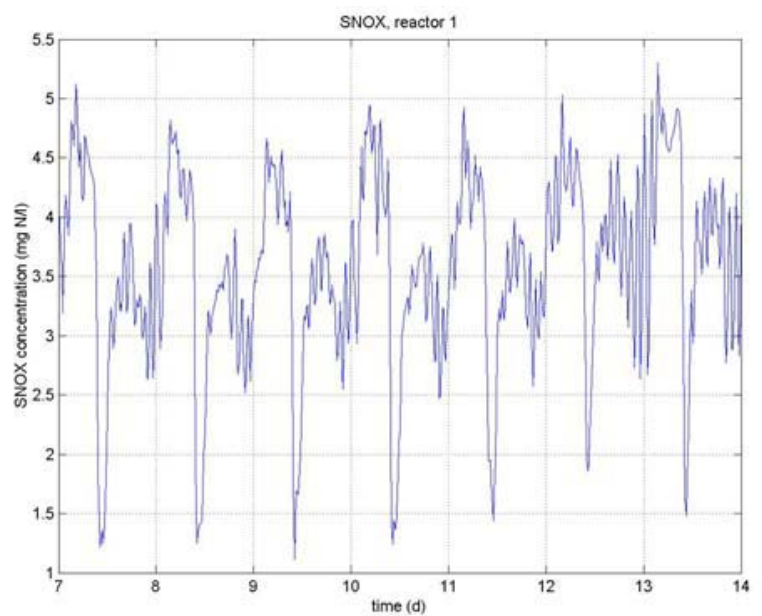

Figure III. $\mathrm{S}_{\text {NOX }}$ concentration resulting from the ASM2d simulation of the WWTP in Figure I (variable dry weather influent, closed loop)

\subsection{Carbon source addition to induce Bio-P removal}

Bio-P removal could be induced by dosing acetate $\left(\mathrm{S}_{\mathrm{A}}\right)$ as a carbon source in the inlet to the first reactor (see Fig. 1). However, the carbon source needed to provoke sufficient $P$ release would be huge, since the competition for $\mathrm{S}_{\mathrm{A}}$ to be used for the denitrification process would be huge. This option was therefore not further investigated. A possible improvement could be a modification of the plant layout, as discussed in 3.2 .

\subsection{Metal salt addition to induce $\mathrm{P}$ removal}

Metal salts can be added to the activated sludge to precipitate $\mathrm{S}_{\mathrm{PO} 4}$ as metal phosphates. In the ASM2d model it is assumed that the metal salt $\left(\mathrm{X}_{\mathrm{MeOH}}\right)$ is $\mathrm{Fe}(\mathrm{OH})_{3}$, whereas the precipitate is assumed to be $\mathrm{FePO}_{4}\left(\mathrm{X}_{\mathrm{MeP}}\right)$.

In a first evaluation it was assumed that a constant flow of concentrated $\mathrm{X}_{\mathrm{MeOH}}(1000 \mathrm{~g} / \mathrm{l})$ was dosed to the inlet of the $5^{\text {th }}$ reactor (last aerobic tank), and the constant influent composition (Table 1) was used as the plant input. It appeared that the ASM2d model reference parameters for the precipitation process $\left(\mathrm{k}_{\text {PRE }}\right.$, rate constant for $\mathrm{P}$ precipitation, $1.00 \mathrm{~m}^{3} / \mathrm{g}$ $\mathrm{Fe}(\mathrm{OH})_{3} . \mathrm{d} ; \mathrm{k}_{\mathrm{RED}}$, rate constant for redissolution, 0.60 $1 / \mathrm{d})$ did not allow reduction of the $\mathrm{S}_{\mathrm{PO} 4}$ concentration to very low values $(<1 \mathrm{mg} \mathrm{P} / \mathrm{l})$ by $\mathrm{X}_{\mathrm{MeOH}}$ addition without a large $\mathrm{X}_{\mathrm{MeOH}}$ overdose. The precipitation kinetics were adjusted because practical experiences had shown that this overdose is not needed. For all further simulations the parameter values $\mathrm{k}_{\mathrm{PRE}}=2.00$ $\mathrm{m}^{3} / \mathrm{g} \mathrm{Fe}(\mathrm{OH})_{3} \cdot \mathrm{d}$ and $\mathrm{k}_{\mathrm{RED}}=0.051 / \mathrm{d}$ were used.

A constant $\mathrm{X}_{\mathrm{MeOH}}$ dosage of $0.6 \mathrm{~m}^{3} / \mathrm{d}$ showed to result in a fair reduction of the $\mathrm{S}_{\mathrm{PO} 4}$ concentrations in the treatment plant effluent. Dosage of $\mathrm{X}_{\mathrm{MeOH}}$ and the subsequent formation of $\mathrm{X}_{\mathrm{MeP}}$ create a substantial additional sludge production. For a constant sludge wastage rate of $385 \mathrm{~m}^{3} / \mathrm{d}$ the sludge concentration in reactor 5 increased to $4555 \mathrm{mg} \mathrm{SS} / 1$, compared to $3502 \mathrm{mg} \mathrm{SS} / 1$ for the scenario with no $\mathrm{X}_{\mathrm{MeOH}}$ addition. The sludge waste rate was therefore increased to $435 \mathrm{~m}^{3} / \mathrm{d}$, which resulted in a sludge concentration in reactor 5 of $4142 \mathrm{mg} \mathrm{SS} / \mathrm{d}$.

The effluent $\mathrm{S}_{\mathrm{PO} 4}$ concentrations simulated for a constant $\mathrm{X}_{\mathrm{MeOH}}$ dosage rate of $0.6 \mathrm{~m}^{3} / \mathrm{d}(=600 \mathrm{~kg}$ $\left.\mathrm{X}_{\mathrm{MeOH}} / \mathrm{d}\right)$, a variable dry weather influent composition, a constant $\mathrm{K}_{\mathrm{L}}$ a of $841 / \mathrm{d}$ in reactor 5 , a constant nitrate recycle flow rate of $55338 \mathrm{~m}^{3} / \mathrm{d}$ and a constant sludge wastage rate of $435 \mathrm{~m}^{3} / \mathrm{d}$ are shown in Figure IV. The plant seems to be able to reach rather low effluent $\mathrm{S}_{\mathrm{PO} 4}$ concentrations with the continuous $\mathrm{X}_{\mathrm{MeOH}}$ addition. The total effluent $\mathrm{P}$ concentration is shown in Figure V. Assuming an effluent total $\mathrm{P}$ limit value of $1.5 \mathrm{mg} \mathrm{P} / 1$, it can be seen that the constant $\mathrm{X}_{\mathrm{MeOH}}$ dosage results in a reasonable $\mathrm{P}$ removal plant performance, taking into account that the effluent $\mathrm{S}_{\mathrm{PO} 4}$ and total $\mathrm{P}$ values for simulations with the same influent for the plant with no $\mathrm{X}_{\mathrm{MeOH}}$ addition (Figure I) were 9.58 and $9.85 \mathrm{mg}$ $\mathrm{P} / 1$ respectively.

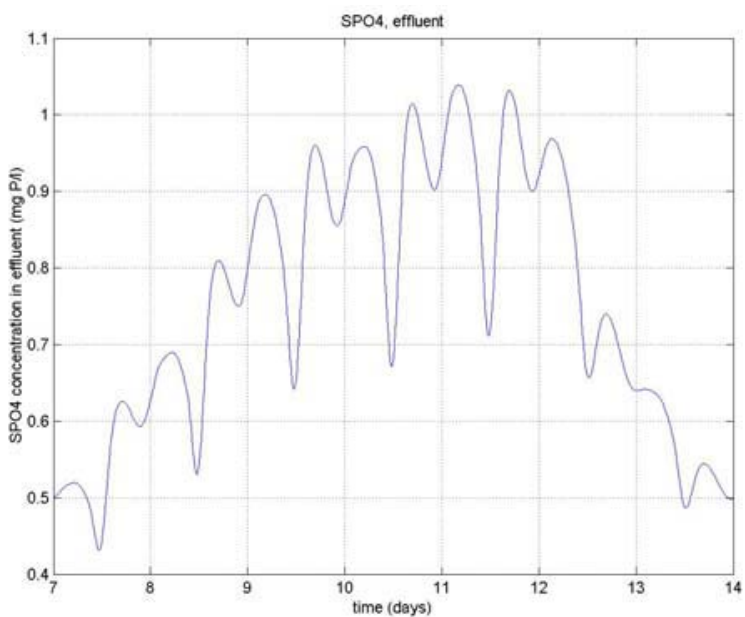

Figure IV. Effluent $\mathrm{S}_{\mathrm{PO} 4}$ concentration resulting from the ASM2d simulation of the WWTP given in Figure

I (variable influent composition, constant $\mathrm{X}_{\mathrm{MeOH}}$ dosage of $0.6 \mathrm{~m}^{3} / \mathrm{d}$ )

In a final phase of the simulations, it was assumed that a $\mathrm{S}_{\mathrm{PO} 4}$ measurement was available in the last aerobic tank. Similar to the $S_{\text {NOX }}$ sensor defined in Copp (2001), a time delay of 10 minutes was assumed for the $\mathrm{S}_{\mathrm{PO} 4}$ sensor, with white, normally distributed (standard deviation of $0.1 \mathrm{mg} / \mathrm{l}$ ) zeromean noise.

A PI controller, similar to the PI controllers used in the ASM1-based simulation benchmark, was implemented for the control of $\mathrm{Fe}(\mathrm{OH})_{3}$ addition. The $\mathrm{Fe}(\mathrm{OH})_{3}$ dosage flow rate was manipulated in order to maintain $\mathrm{S}_{\mathrm{PO} 4}$ at a set point of $0.8 \mathrm{mg} \mathrm{P} / 1$ in the last aerobic tank. (see Figure VI). The maximum $\mathrm{X}_{\mathrm{MeOH}}$ solution dosage flow rate was constrained to 3 $\mathrm{m}^{3} / \mathrm{d}$. 


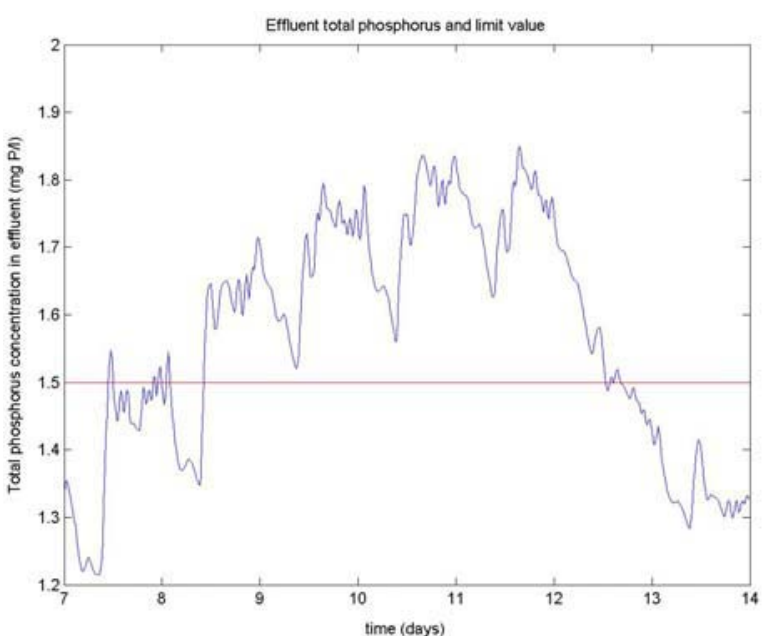

Figure V. Total effluent $\mathrm{P}$ concentration resulting from the ASM2d simulation of the WWTP in Figure I (variable influent composition, constant $\mathrm{X}_{\mathrm{MeOH}}$ dosage of $0.6 \mathrm{~m}^{3} / \mathrm{d}$ )

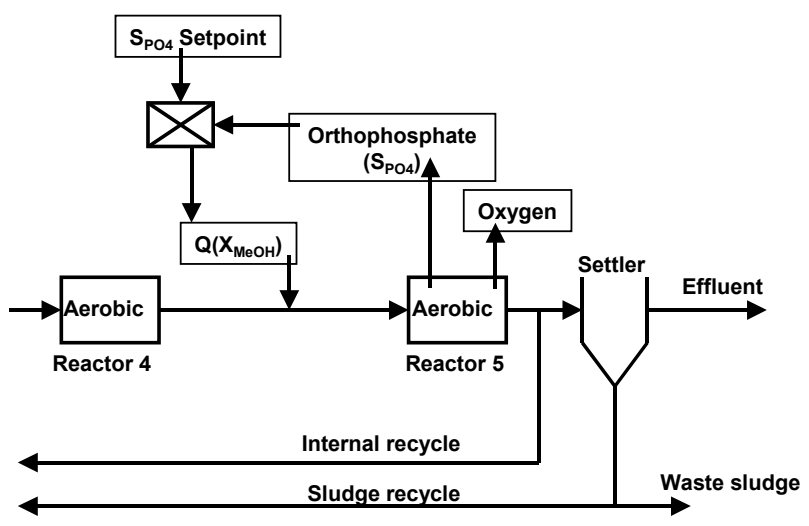

Figure VI. Illustration of the $\mathrm{X}_{\mathrm{MeOH}}$ dosage control strategy $\left(\mathrm{Q}\left(\mathrm{X}_{\mathrm{MeOH}}\right)=\mathrm{X}_{\mathrm{MeOH}}\right.$ solution dosage flow rate)

The proportional gain for the PI controller was set equal to $-51 /($ d.mg P.l), whereas the integral time constant and the anti-windup time constant were set equal to $0.002 \mathrm{~d}$ and $0.0002 \mathrm{~d}$, respectively. The controller was used to illustrate the ASM2d benchmark WWTP control possibilities. The control performance for the $\mathrm{S}_{\mathrm{PO} 4}$ concentration in the last aerobic tank for the simulation with the $\mathrm{X}_{\mathrm{MeOH}}$ dosage controller (variable dry weather influent composition, fixed waste sludge flow rate of 435 $\mathrm{m}^{3} / \mathrm{d}$ ) is illustrated in Figure VII. It should be stressed here that it was not pursued at this stage to tune the controller parameters for optimal control performance. Important at this point is to investigate the response of other process variables to the implementation of the controller. The average effluent total P concentration (Figure VIII) is 1.55 $\mathrm{mg} \mathrm{P} / \mathrm{l}$, which is close to the effluent total $\mathrm{P}$ limit of $1.5 \mathrm{mg} \mathrm{P} / 1$. The effluent $\mathrm{S}_{\mathrm{PO} 4}$ concentration is however fluctuating around the $\mathrm{S}_{\mathrm{PO} 4}$ set point for reactor 5 (average effluent $\mathrm{S}_{\mathrm{PO} 4}$ concentration of 0.71 $\mathrm{mg} \mathrm{P} / \mathrm{l})$.

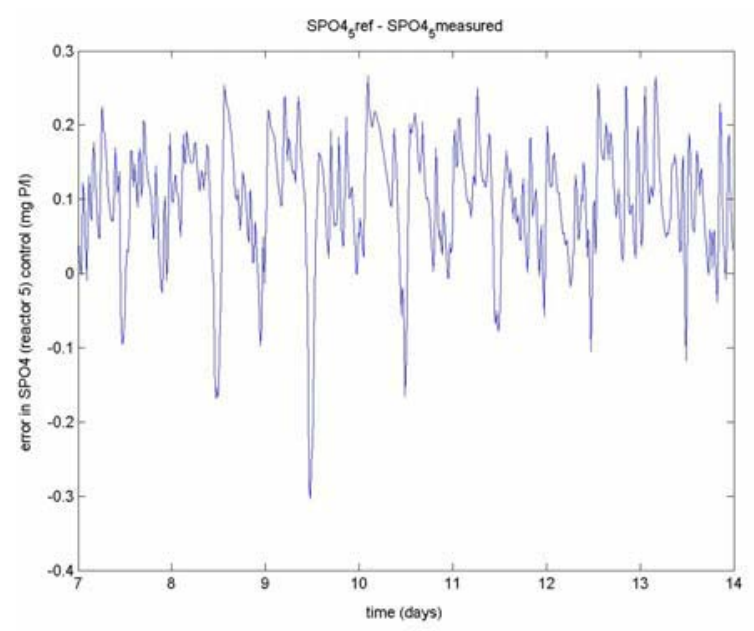

Figure VII. Performance $\left(\mathrm{S}_{\mathrm{PO} 4, \mathrm{ref}}-\mathrm{S}_{\mathrm{PO} 4 \text {,measured }}\right)$ for the $\mathrm{X}_{\mathrm{MeOH}}$ addition controller simulation (variable dry weather influent composition, fixed waste sludge flow rate of $435 \mathrm{~m}^{3} / \mathrm{d}$ )

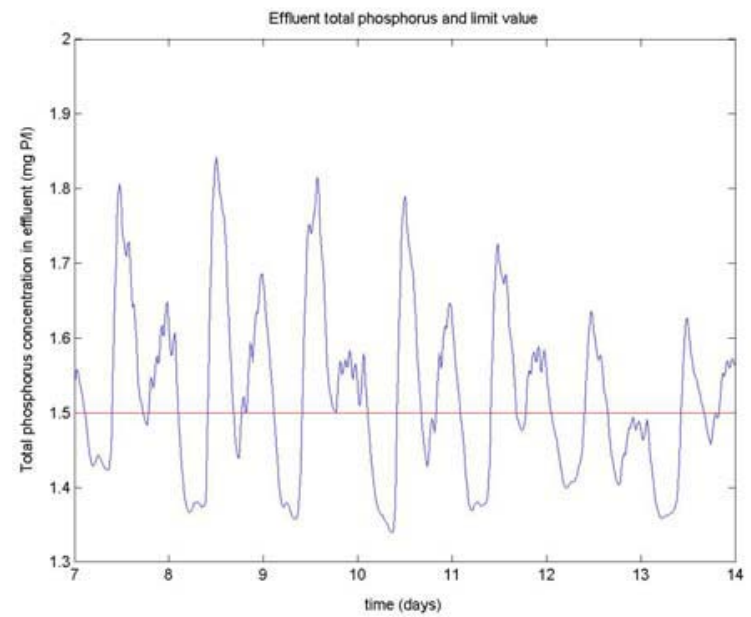

Figure VIII. Effluent total P concentration for the $\mathrm{X}_{\mathrm{MeOH}}$ addition controller simulation (variable dry weather influent composition, fixed waste sludge flow rate of $435 \mathrm{~m}^{3} / \mathrm{d}$ )

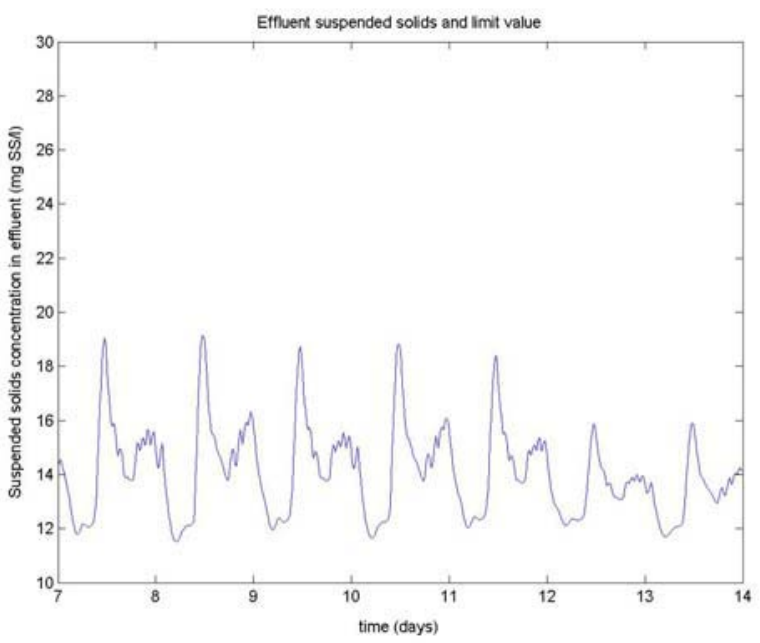

Figure IX. Effluent SS concentration for the $\mathrm{X}_{\mathrm{MeOH}}$ addition controller simulation (variable dry weather influent composition, fixed waste sludge flow rate of $\left.435 \mathrm{~m}^{3} / \mathrm{d}\right)$ 
The large difference between average effluent $\mathrm{S}_{\mathrm{PO} 4}$ and total $\mathrm{P}$ means that there is quite some organic $\mathrm{P}$ leaving the plant, i.e. $\mathrm{P}$ associated with the SS. By comparing Figure IX with Figure VIII one can indeed observe that the peaks in the effluent total $\mathrm{P}$ concentration (Figure VIII) coincide with the effluent SS peaks. One reason for this correlation is that the suspended solids contain considerably more $\mathrm{P}$, because the $\mathrm{P}$ is precipitated and adsorbed to the sludge flocs. Indeed, the sludge consists of about $20 \% \mathrm{X}_{\mathrm{MeP}}$ for the $\mathrm{X}_{\mathrm{MeOH}}$ addition scenario. Another reason is the higher sludge concentration for this scenario compared to a scenario with no $\mathrm{X}_{\mathrm{MeOH}}$ addition, resulting in a slightly higher effluent SS concentration for the scenario with $\mathrm{X}_{\mathrm{MeOH}}$ addition (14.52 mg SS/1 versus $13.43 \mathrm{mg} \mathrm{SS} / 1$ ). A next step in the development of this case study would thus be to investigate how the effluent SS peaks can be reduced. Creating extra sedimentation tank volume is an option, since it will reduce the load to the secondary clarifier. Alternatively, one could also try to better control the sludge load to the clarifier, e.g. by implementing a waste sludge flow rate controller that keeps the SS concentration in the aeration tanks at a operator defined setpoint of e.g. $4000 \mathrm{mg} \mathrm{SS} / 1$. In the presented simulation the SS concentration in reactor 5 varied between 3500 and $4500 \mathrm{mg} \mathrm{SS} / 1$.

Finally, the $\mathrm{X}_{\mathrm{MeOH}}$ addition has an influence on the effluent $\mathrm{N}$ concentration, mainly due to the extra sludge production and the increase of the waste sludge flow rate to $435 \mathrm{~m}^{3} / \mathrm{d}$. Although the total average effluent $\mathrm{N}$ has only marginally increased from 19.08 to $19.52 \mathrm{mg} \mathrm{N} / 1$ compared to the scenario without $\mathrm{X}_{\mathrm{MeOH}}$ addition, the $\mathrm{X}_{\mathrm{MeOH}}$ addition scenario performs considerably worse for the $\mathrm{S}_{\mathrm{NH} 4}$ removal (average effluent conc. $=6.13 \mathrm{mg} \mathrm{N} / \mathrm{l}$ ) compared to the scenario without $\mathrm{X}_{\mathrm{MeOH}}$ addition (average effluent conc. $=4.77 \mathrm{mg} \mathrm{N} / \mathrm{l}$ ). A way to optimise the nitrification process would be an increase of the aeration capacity and/or the $\mathrm{S}_{\mathrm{O} 2}$ set point in the last aerobic reactor. A complete investigation of the different operational options to obtain $\mathrm{P}$ removal from wastewater should thus include operating costs, effluent quality related parameters and, if possible, capital costs (e.g. in case one considers extension of the plant capacity, or cost of implementing a control loop on the plant).

\section{CONCLUSIONS}

A benchmark wastewater treatment plant based on the ASM2d model can be a useful example to evaluate $\mathrm{P}$ removal control strategies in a WWTP. For process optimisation, it should be realised that the steps taken to optimise $\mathrm{P}$ removal may have a large influence on other important process parameters such as the effluent $\mathrm{N}$ and $\mathrm{SS}$ concentrations.

\section{ACKNOWLEDGEMENTS}

The authors wish to thank Ulf Jeppsson (IEA, Lund University of Technology, Sweden) for providing the ASM1 benchmark Matlab/Simulink code. The work received support of the European Commission, in the frame of the SMAC (SMArt Control of Wastewater Systems) project (contract number EVK1-CT-200000056).

\section{REFERENCES}

Barker P.S. and Dold P.L. (1997) General model for biological nutrient removal activated-sludge systems: Model presentation. Water Environ. Res., 69, 969-984.

Brdjanovic D. (1998) Modelling biological phosphorus removal in activated sludge. $\mathrm{PhD}$ thesis. Delft University of Technology, The Netherlands.

Copp J. (2001) The COST simulation benchmark: Description and simulator manual. Office for official publications of the European Community, Luxembourg. $154 \mathrm{pp}$.

Henze M., Grady C.P.L. Jr., Gujer W., Marais G.v.R. and Matsuo T. (1987) Activated sludge model No. 1. Scientific and technical Report No. 1, IWA Task Group on Mathematical Modelling for Design and Operation of Biological Wastewater Treatment.

Henze M., Gujer W., Mino T., Matsuo T., Wentzel M.C., Marais G.v.R. and van Loosdrecht M.C.M. (1999) Activated sludge model no. 2d, ASM2d. Water Sci. Technol., 39(1), 165 - 182.

Henze M., Gujer W., Mino T., Matsuo T., Wentzel M.C.M. and Marais G.v.R. (1995) Activated Sludge Model No. 2. IWA Scientific and Technical Report No. 3, London, UK.

Pons M.N., Copp J., Jeppsson U. and Spanjers H. (2001) Benchmarking the evaluation of control strategies in wastewater treatment: The four-year story of the COST benchmark. In: Proceedings $8^{\text {th }}$ International Conference on Computer Applications in Biotechnology (CAB8), June 2427 2001, Quebec, Canada, p 231-237.

Pons M.N. and Corriou J.P. (2001) Implementation of storage tanks on the COST 624 benchmark. In: Proceedings $1^{\text {st }}$ IWA Conference on Instrumentation, Control and Automation, June 37 2001, Malmö, Sweden, p 253-259.

Takacs I., Patry G.G. and Nolasco D. (1991) A dynamic model of the clarification-thickening process. Water Res., 25, 1263 - 2171 